\title{
Policy on Prisoners, Sex Offenders with Mental Disorders: Practice of Germany and Some Other Countries and Recommendations for Vietnam
}

\author{
Le Lan Chi* \\ VNU School of Law, 144 Xuan Thuy, Cau Giay, Hanoi, Vietnam \\ Received 06 October 2017 \\ Revised 30 November 2017; Accepted 28 December 2017
}

\begin{abstract}
Mental disorders have nagative impacts on prisoners, sex offenders serving sentences and on the realization of the objectives of rehabilitation and crime control. That is why many nations have issued particular policy on such target groups. This paper identifies the grounds and contents of the policy and offers reccommendations to Vietnam, thus contributing to the guarantee of human rights as well as to the addressing of related current practical issues of criminal justice in Vietnam.
\end{abstract}

Keywords: Mental disorders, prisoners, confinement facilities, therapeutic treatments, sex offenders, penalty, chemical castration, surgical castration

\section{Introduction}

Prisoners are subjects with a particularly high frequency of mental disorders due to a previous history of psychiatric illness or a direct impact of the custody process. Insecure mental health results in negative consequences not only to the process of rehabilitating and restoring the dignity of criminals but also to the instability for other prisoners, security, and safety of the prison. Offenders of sexual crimes with mental health issues are also in need of care and have to be subjected to specific policies in order to resolve the root cause of the crimes and prevent the possibility of recidivism. These issues have been studied and provided with legal and

\footnotetext{
* Tel.: 84-24-37547512.

Email: lelanchi@vnu.edu.vn

https://doi.org/10.25073/2588-1167/vnuls.4121
}

medical remedies for the practical enforcement of prison sentences in Germany and other countries in the world. Viet Nam also states a mandatory treatment in the Penal Code and formulates the procedure for applying this measure as a particular procedure in the Criminal Procedure Code, Law on Execution of Criminal Judgments and by-law documents. Nevertheless, it is necessary for Viet Nam to continue complement its policies for criminals with mental ill and sexual crimes, especially in the context of overcrowded prisons and the increasing and evolving complexity of sexual crimes in Viet Nam.

This paper stems from primary concepts of mental health and mental illness which is mental disorder; general descriptions of mental health of criminals in general; specific cases of inmates convicted of sexual offenses and the analysis of their causes, an introduction of 
policies towards this issue in Germany and some other countries such as the United States, England, Denmark. This research thereby offers recommendations for Viet Nam, a nation under the great pressure to advance the criminal justice system in both directions of guaranteeing human rights of inmates and successful rehabilitation, improving the effectiveness of crime prevention, crime and recidivism control. This paper does not put high priority on mental health measures for prisoners, psychiatric treatments, causes of sexual offenses or its related legal issues but emphasizes on clarifying polices for dealing with mentally ill prisoners and especially for those who are charged with sexual offenses.

\section{Prisoners and sex offenders with mental disorders}

\subsection{The confinement environment and the mental disorders of the prisoners}

Mental health is a medical term which can be expressed in different ways, whereas basically can be explained as the ability of the psychological machine to operate in a reasonable and satisfactory manner, to flexibly cope with harsh circumstances but to maintain the balance at the same time. In a modern society, the more people are facing various contexts, adapting to different roles and meeting different requirements, the harder it is to sustain a good mental health and to maintain the balance. A good mental health refers to the condition, in which people show no mental disorder and their mental state is stable. Causes of mental disorders and mental health comprise physical issues due to brain damage, cerebral diseases or brain impairment, abnormal physical constitution, and psychological problems, in particular when patients are addicted to stimulants such as alcohol, drugs or they are under pressure both physically and mentally.

The confinement environment has a severe negative impact on the mental health of prisoners. When living in a confinement environment such as prisons or detention centers, prisoners have to face a reality of deprivation of liberty and restrained connection with families and friends; their physical, mental and sexual demands are not met as they are supposed. They also have to confront the sin committed to the victims or the inferiority complex they cause for their own families and society. The monotonousness and repeat of daily life within the prison lead the confined to a sense of boredom and deadlock. The unreasonable prison regime results in an imbalance between the collective and individual lives, between the communicating demand with the society and the demand for the privacy to be respected and so forth, exerts a negative influence in both the physical and mental lives of the convicted. Moreover, there are several correction facilities in which dietary conditions are insecure, leading to hunger, thirst, malnutrition and diseases. These hardships aggravate the struggle of the offenders to preserve their dignity and ethical autonomy. But more than that, the dominance of order and internal rules in the criminal world imposed by criminals themselves and the treatment by prisoners threaten the rehabilitation process and self - education reforms. Inmates have the tendency to integrate or co-exist with this order to guarantee their safety and avoid to be separated in the prison - the community they are living in. This phenomenon constructs 'the crowd effect', which tends to violate the order and regulations formed by the prison authorities and criminal justice authorities, causing opposition or even uprisings of prisoners within the confinement.

On the other hand, in respects of many inmates, they themselves have been subjected to their own mental disorder. Those issues of mental health partially contributed to their criminal offenses and their confinement. Even though they are suffering from a mental disorder while committing criminal offenses, why do they have to be arrested and confined? The reason behind this is the pressure that 
society puts on the government on the issue of controlling criminals. Why is a person with mental illness arrested rather than taken to a hospital? Generally, persons who are suspected to have committed a felony are arrested and brought to jail regardless of their mental condition. The criminal justice system, charged by society with the responsibility for removing people accused of committing serious crimes from the community, sees no alternative but to first place the person in the secure setting that is custody and then arrange for psychiatric treatment if necessary. 'If the person is thought to have committed a serious crime, the police and the criminal justice system generally do not want to leave this person in a psychiatric hospital where security may be lax, the offense may be seen by staff as secondary to the patient's illness, and the person may be released to the community in a relatively short time' [1] and 'The mentally ill may be more likely to be arrested because of the police officer's perception that a warning to a mentally ill person may serve no useful purpose, or that the individual's behavior is considered to be too unpredictable, so some intervention is necessary' [2].

Using and depending on stimulants causes serious mental illness. Among criminals, the amount using drugs is extremely high. According to statistics in Viet Nam, in 2012, 7.194 convicted persons were addicted, in 2013 the number was 6.831 and in 2014 there were 5.660 persons [3]. In Germany, 'approximately 30 percent of the inmates are addicted to a substance, and the lifetime prevalence of misuse is even higher (Keppler et al., 2010)' [4], the addicted account for $47 \%$ prisoners in Switzerland and $32 \%$ ones in France and, in the UK, the Home Office (2003) reported that around $73 \%$ of recently sentenced prisoners had used illegal drugs in the 12 months before imprisonment [5]. Thus, the incidence of blood or sexually transmitted diseases is particularly high. For instance, in England and Wales, the average number of HIV-positive offenders is 15 times higher than the outside community. In
Viet Nam, 11.680 HIV offenders $(1,741$ people switched to AIDS) account $8.9 \%$, of prisoners [6].

What is more, with differences in negative personal identities and low educational attainment, offenders find it harder to gain the necessary understanding to attain psychological autonomy and mental health for themselves. To illustrate this, in England and Wales, the average number of criminals when compared to those in society are "13 times more likely to have been in care as a child, 10 times more likely to have been a regular truant from school, 13 times more likely to have been unemployed, 2.5 times more likely to have a family member who has been convicted of a criminal offense, 6times more likely to have been a young father" [7]. They have a low educational degree and lack the skills to integrate in modern society: " $80 \%$ have the writing skills of an 11-year-old, $65 \%$ have the numeracy skills of an 11-yearold, $80 \%$ have the reading skills of an 11-yearold" [8].

To summarize the above reasons, the ratio of offenders with mental illness is particularly high. In England and Wales, the SEU found that " $70 \%$ of all prisoners suffer from at least two mental disorders. This was in accordance with the findings of the Office for National Statistics in 1977 , which state that $78 \%$ of male remand prisoners, $64 \%$ of male sentenced prisoners, $50 \%$ of female prisoners ware suffering from a personality disorder (Office for National Statistics 1998)" [9]. In other European countries, the incidence rate is supposed to be high but there is no specific data: "Despite a reported increase of mental health problems among prisoners in Europe and worldwide, official data on the frequency of psychiatric cases or the diagnoses in prisons are scarce. Most European countries included in this study do not run psychiatric prison registers or have available routine information on the frequency of mental disorders among their prison population" [10]. The above situation is evaluated: "This is a most serious omission, which is not moderated by the fact that 
similarly sensitive fields (e.g., forensic psychiatry) suffer from the same shortcomings. Without basic morbidity data, the extent and burden of mental disorders in prisons will remain unclear and any analyses focussing on the appropriateness of mental health care in prisons will be blocked" [11]. In the US, $10 \%$ up to $15 \%$ inmates in state prisons cope with severe mental illness [12]. Prisoners with mental ills have becoming a serious challenges to criminal justice systems, a heavy burden to correction authorities.

\subsection{Sex offenders and the mental disorder}

For sexual crimes such as rape, sexual assault or sexual abuse (taking advantage of the power to sexually harass or seduce, coerce others to have sexual-intercourse), many of the offenders show symptoms of mental issues that lead to sexual disorders (paraphilia disorders). There are some sexual disorders which are deviant and harmless for others such as masochism - causing self-inflicted pain when having sex or exhibitionism - exposing genitals in front of others. However, there are other sexual disorders violating privacy, health, honor, dignity or even lives of others namely voyeurism (peeking others bathing, dressing, having sex), frotteurism (rubbing their sexual organs on others' body), sexual fetishism (taking others' objects to imagine having sex with them), sadism (sexual disorders proactively causing pain - physically hurting others when having sexual intercourse), pedophilia (having sex with children), necrophilia (having sex with corpses) and incest (having sex with close relatives). When losing self-control, those people can attack, threaten or entice others to have sex with them. Roots of those sexual ailments are usually originated from previous psychological disorders during childhood or adolescence. They used to be sexually abused; be proactive or passive in studying, imitating behaviors of sexual disorders from adults or movies. Additionally, studies in the United States show that $74 \%$ sexual disorders stem from hormone disorders,
$24 \%$ come from genetic disorders and $27 \%$ are due to neurological damage. Hormone disorders happen, when sexual hormones of male testosterone - elevate exceptionally resulting in intense sexual arousal and obsession, then losing awareness, control and disregarding any methods or frameworks to achieve the satisfaction of sexual maturation.

Consequently, sex crimes must be condemned morally, but at the same time, for some people, they are also a form of mental illness worthy receiving sympathy and treatment during and after they serve their criminal responsibilities to help them recover ailments and bring safety to the society.

The concerning matter is that the number of sexual offenders is extremely considerable. For example, in the US: 'Rape and sexual assault offenders account for just under $5 \%$ of the total correctional population' [13]. In the confinement environment, without caring and treatment, psychiatric illness of inmates may continue to be aggravated since they either hide, self-restrain or engage in similar behaviors they had been convicted of to satisfy their sexual needs; In peculiar, they have the potential to develop other mental disorders. It is because 'Sex offenders are perceived as occupying the lowest possible rung within the prison social hierarchy, not only among inmates, but also among custodial and often treatment staff. This leads to extreme secrecy and fear of selfdisclosure based on a legitimate fear for their safety' [14].

\section{Handling of prisoners with mental disorders in germany and some other countries}

\subsection{Germany}

Almost all European countries, being member states of the ECHR, stress the aim of rehabiliatation and re-socilization with the beilief that prisoners are eligible to bear kind treatment of the society and thus, prisoners 
could realize the value of kindness, the role of the rule of law and of law observance. Thanks to that perspective, the prison system is organized around and focused on the pillars of rehabilitation and re-socialization. The above mentioned aim is the strong confirmation of principle stated Article 10 para. 3 of the International Convenant on Civil and Politic Rights 1966: "The penitentiary system shall comprise treatment of prisoners of which the essential aim shall be their reformation and social rehabilitation".

The Federal Act concerning the execution of prison sentences and measures of rehabilitation involving deprivation of liberty of Germany (German Prison Act) defines rehabilitation measures for prisoners. This results in a better life for inmates after their release and prevents the society from reoffenses as well. As the results, therapeutic treatments at social therapeutic institutions (seperatedly located from other units of prison), are popularly applied upon prisoners with mental illness and prisoners convicted of sexual offences stipulated from Section 176 to Section 180 of the German Penal Code. Section 7 of the German Prison Act considers the transfer to a social therapeutic institution as one of 8 treatment measures applied to prisoners. According to Section 9, "A prisoner shall be transferred to a socio-therapeutic institution if he has been sentenced to more than two years' time-limited imprisonment regarding a criminal offence in accordance with Sections 174 to 180 or 182 of the Criminal Code", and "The prisoner shall be transferred back if the purpose of the treatment cannot be achieved for reasons inherent in the prisoner's personality". These measures are used for inmates during their rehabilitation, the treatment measures are also discussed with the prisoners and their willingness is encouraged. They are distinct with "measure of rehabilitation and incapacitation" as "mental hospital orders" sentenced to offenders in insanity or offenders who diminish responsibility, and "custodial addiction treatment orders" sentenced to offenders while they were intoxicated or as a result of addiction, stated in Section 61, 63, 64 of the Criminal Code, applied by the Court.

"The German code of criminal procedure includes regulations for the release of prisoners in cases of severe mental illness and lifethreatening diseases (Strafprozessordnung, 2010). If patients are already in prison, the punishment can be discontinued in such cases. One important factor is that punishment can be discontinued if a health problem cannot be treated within the prison system. For example, in the State of Berlin, there are no psychiatric beds for female offenders within the system. In all cases of interrupted imprisonment, the goal is to reduce relevant security risk for the community. Otherwise, the inmates must stay in prison even if they cannot be treated there. However, patients can be brought out of prison to public institutions or hospitals for treatment, as prisoners ( $§ 65$ Strafvollzugsgesetz, 2011). Under these conditions, the prison system is responsible for ensuring that the patient does not escape. This is routinely done by shackling prisoners. Under these conditions, confidential psychiatric treatment is not possible, especially when intensive treatment is required. In addition, the prison system is not interested in creating further security problems and must take on the burden of providing resources including security, which can take weeks or months. Furthermore, the prison system must pay for treatment costs from its own budget. In Germany, general health insurance is suspended once a person is imprisoned" [15].

In conclusion, the legal framework of Germany on psychiatric treament for convicted prisonsers is rather synchronous, from the Prison Act, the Penal Code to the Criminal Procedure Code, thus contributing to a flexible legal mechanism to an early and longlasting intervention for the convicted, through their process of serving imprisonment sentence, even subsequent to their releases [16]. In practice, the appearances of social-therapeutic units in the prison systems of almost Länder (states) in Germany guarantees the specific treatment needed 
for prioners with mental illness. However, the lack of psychiatric expertises with professional training has lead to certain unexpected outcomes of the treament; the evaluation on scale and capacity of the treament is also not easy because of isufficiently updated data.

\subsection{Other countries}

Because the prison population in the US tends to be incarcerated for longer periods than jail inmates, treatment possibilities in a prison setting are more extensive, depending on funding and other factors. Counselors and prison administrators may establish programs that are long term and comprehensive. Substance abuse issues may be addressed along with behavioural, emotional, and psychological problems. Ideally, prisoners have the opportunity to abstain from substances and learn new behaviours before release [17]. Main program components are: Community meetings, events, and ceremonies; Seminars; Group encounters; Group therapy; Individual counseling (both from staff and peers); Tutorial learning sessions; Remedial and formal education classes; Client job-work responsibilities; Explicit treatment phases that are designed to provide incremental degrees of psychological and social learning.

In England and Wales, prisoners, whether on remand or sentenced, who are suffering from a serious form of mental disorder (i.e. psychotic illnesses or severe mood disorders) and are deemed in need of hospital treatment, are transferred out of the prison system into psychiatric hospitals of the National Health Service (NHS), either general or forensic, depending on the clinical needs of the patient. Compulsory treatment is not permitted in prisons under the Mental Health Act 1983, because there are no hospitals in prisons. Prisons contain "health care wings", but these are not designated as hospitals and there are no psychiatric "wards" within the prison system.

The care of the mentally-ill in prisons therefore falls into two halves: the identification of a serious mental disorder and the implementation of mechanisms to transfer prisoners out of the prison system, and efforts to offer treatment for a less serious mental illness, personality difficulties and substance abuse problems within the prison estate. Those sentenced to prison terms who are subsequently found to be suffering from serious mental illness are transferred out from prisons into NHS hospitals. Once there, some may be returned to prison when they improve, but many will complete their sentences in NHS hospitals [18].

Nevertheless, England and Wales also have insufficient data on the treatment of psychometric prisoners, on the process and results, lack of professional medical staff for treatment of mentally ill people and lack of standards of mental care for prisoners.

In Denmark, prisoners during their admission period are taken to a medical examination to determine whether they suffer from a mental illness or not. If there are grounds to believe that prisoners have a mentaldisorder, they shall be transfered to a psychometrist, after that, under decisions of the Court, they are treated at expertised mental care units as in-patients or out-patients.

All confinement facilities have part-time psychiatrists to practice short time treatment for prisoners, evaluating the status of a prisoners' mental disorder to consult, to cure them right in the prisons or transfer them to Herstedveste Institute. In general, prisoners are regularly watched by line officers and social workers in their course of work, training and living. Psychiatrists are consulted when it is necessary to take their opinions into consideration before a prisoners' release or parole. Inmates are entitled to exam and to treat in hospital [19].

\section{Handling of sexual offenders with mental disorder in germany and other countries}

\subsection{Germany}

Germany is one of the countries in which the voluntary surgical castration of sexual 
offenders remains. The legal requirements for the application of surgical castration are set out in the (federal) Law on Voluntary Castration and Other Methods of Treatment of 1969 ("Law on Voluntary Castration"). According to Sections 2 and 3 of the aforementioned law, a person may be the subject of surgical castration, at his own request, if: (a) the intervention is indicated, in the light of the latest findings of medical science, in order to prevent, cure or alleviate severe illness, mental disorder or suffering which are related to an abnormal sex drive, or (b) a person displays an abnormal sex drive, which, on account of his personality and past life, gives reason to suspect that he will commit one or more criminal offences enumerated in the law (in particular, murder, manslaughter, rape, sexual abuse of children, severe bodily injury, or exhibitionism) and that castration is indicated in the light of the latest findings of medical science, in order to counter that risk and thus to support the person concerned in managing his life.

In term of proceedings, before giving his consent, the person concerned must be informed about the reasons, implications and side effects of the castration as well as other treatment possibilities. They have to meet the following conditions: (1) minimum age of 25 years; (2) the castration will not lead to physical or psychological adverse effects which are disproportionate to the aspired aim of the intervention; (3) medical examination and positive evaluation by an expert commission (Gutachterstelle) of the medical chamber of the respective Land; 4, approval of the guardianship court (applicable only when the person concerned is not able to give a valid consent). After all, necessary legal proceedings shall be applied based on the consent of the offenders. A commission (with two doctors including a psychatrist and one lawyer as the requirement of the Court) shall consider a medical report on the situation of the offender with related judicial and administrative issues, subsequently, the commision will send all information to the offender to ensure that they do understand their cases.

Pursuant to the Law on Voluntary Castration and Other Methods of Treatment of 1969, in respect of the person concerned being deprived of his liberty (i.e. prison, forensic psychiatric hospital, preventive detention), he must be informed that surgical castration does not entail entitlement to early release, must give his consent by signing a statement to this effect and must also be advised to undergo medical checks after the intervention; his spouse must be consulted, unless the latter is opposed to it, or such a consultation appears to be inappropriate. Then, the expert commission decides by majority; a positive decision is valid for one year; if the castration is not performed within one year, the authorization can be renewed once for another year (upon request). The Law of the respective Länder shall define in detail the proceeding and the competences to perform the castration.

However, there has been strong official protest against this practice, according to a Report to the German Government on the visit to Germany carried out by the European Committee for the Prevention of Torture and Inhuman or Degrading Treatment or Punishment (CPT) from 25 November to 7 December 2010: Firstly, such an intervention has irreversible physical effects; it removes a person's ability to procreate and may have serious physical and mental consequences; Secondly, surgical castration is not in conformity with recognized international standards. As a matter of fact, new methods of treatment have been developed); Thirdly, there is no guarantee that the result sought (i.e. lowering of the testosterone level) is lasting. Regarding the re-offending rates, the presumed positive effects are not based on sound scientific evaluation. In any event, the legitimate goal of lowering re-offending rates must be counterbalanced by ethical considerations linked to the fundamental rights of an individual; Fourthly, given the context in which the intervention is offered, it is 
questionable whether consent to the option of surgical castration will always be truly free and informed; the Act should be promptly discontinued because such an intervention has irreversible physical effects; it removes a person's ability to procreate and may have serious physical and mental consequences [20].

\subsection{Other countries}

In the US, as in Germany, provisions on castration also raise concern about the context in which the offenders render their discretions, whether they possess enough medical information and psychological consultants to decide. On the other hand, the fact that prisoners should undergo castration needs to derive from their history of mental and physical health, but reason is that one can commit a sexual offense in various situations, stemming from various causes. However, according to the statements in law, castration measures including surgical and and chemical one has received comments that legislators had suffered from the pressure of society to act, without sufficient compelling grounds, and the legislation should have to be the joint consideration of three sides: legislators, criminal justice practioners, and medical experts.

Subsequent to judgment between chemical and surgical castration, the offenders tend to choose the chemical one. Chemical castration is performed by injecting some doses of medicine into the patients ${ }^{6}$ blood to reduce the amount of testosterone. This measure does not seem to cause debate, in fact, in this case the debate is centered around its effectiveness. What is the real length of the effectivenees, what is the decline of sexual drive? And, the most important fact is this: usage of chemicals to perform castration could change/exert control over the offenders' mind and thus could violate the freedom of thought and speech [21].

On the other hand, in some states of the US, to enjoy parole or probation offenders have to choose castration. California requires offenders to have a castration performed on them before their release. Texas is the first state who presently applies castration measure to recidivists upon their consent. Recidivists in Illinois, Ohio and Arkansas can have their sentence reconsidered after castration. Surgical castration, in theory, is an effective measure, as its nature is to cut off genitals, the organ which produces $95 \%$ of the male hormones. Surgical castration has been proven to reduce sexual drive in many offenders, according to several studies. A German study showed a recidivism rate of 3 percent for castrated offenders, compared to 46 percent for non-castrated offenders [22]. Nonetheless, in clinical point of view, some experts supposed that after the surgery, some patients could recover some of their sexual functions and some others, could use medicine to supplement testosterone. In additions, to strengthen the protest against surgical castration, it is said that other psychiatric or psychological therapeutic treatments could be implemented as an effective replacement for castration. So, provisions of surgical castration are supposedly a matter of politics rather than a matter of medical care.

Vice-versa, the US is known as a country with abundant post-release programs to supervise and control sex offenders when they return to society. Based on Violent Crime Control and Law Enforcement Act of 1994, each State requires sex offenders to register their personal information with a certain frequency to assist the police. Data registry is also released upon suggestions of relevant individuals and organizations. Department of Corrections has competence to make public all necessary information for warning of re-sexual offenses. To safeguard for the community, sexual offenders shall be controlled in the following manners:

+ Control over accommodation: the offenders must register their stays in detail, which are required to be far away from the shelter of victims or the ones who are in danger of being victims. The offender must utilize electronic devices for remoted 
supervision or are compelled to live in his shelter, to receive regular or irregular exams of correction officers and lawyers of the victims.

+ Control over communication and traveling: the offenders must provide driving itinerary, report on their routes, departments and arrivals.

+ Control over accessing information to prevent the offenders from the purchase or reading of pornographic images, pictures, magazines or even from logging into the Internet.

+ Control over medical treatment: the offenders must supply blood samples for DNA experiment to serve other investigations, to undergo electrocardiogram (ECG), to measure the reaction and the dimension of the genitals with outside excitement factors. The offenders need to attend training courses and treatment courses (and even single psychiatric treatment courses if it is a case of a special sexual disorder) to improve their understandings and to adjust their behavior.

In England and Wales, sex offender treatment programmes are mandatory for most categories of sex offenders. Whilst forensic psychiatry services may have a role in providing multi-disciplinary sex offender treatment programmes, sex offender programmes are not generally part of overall health care commissioning arrangements. Sexual offenders do not generally have mental health problems, and sexual paraphilias and disorders of sexual preference are specifically excluded from the scope of the Mental Health Act. Services are provided in prison on a group basis, generally by non-clinical psychologists employed by the prisons [23].

In Denmark, since 1997, the country has launched a nationwide treatment programme for sex offenders carried out in collaboration between the psychiatric health-care system and the Department of Prisons and Probation. Offenders who have committed non-violent sexual crimes and who are motivated for treatment might receive suspended sentence on condition of psychiatric/sexological treatment. The treatment takes place at one of three psychiatric facilities, all of which are departments of university psychiatric clinics. Based on individual needs, the clinics offer counselling, cognitive therapy, psychoanalytically oriented psychotherapy or group therapy, together with psychopharmacological treatment if indicated. An offender is also under the supervision of a probation officer, who is responsible for social support and help in cooperation with the local social authorities.

Offenders who have committed more serious sexual crimes receive ordinary sentences. The imprisonment, however, starts with a short stay in a special unit at the Herstedvester institution with purpose of examining an offender's motivation for treatment, and if needed, to motivate him for treatment. Treatment-motivated offenders then serve their sentence in open prison and receive psychiatric/sexological treatment as previously described. The most dangerous sex offenders are not included in the programme, but are still offered treatment during their imprisonment in Herstedvester [24].

\section{The situation in Vietnam and recommendations}

There have not been any official statistics about mental health issues in Viet Nam, according to the Ministry of Health, Health Management Department, mental disorder is one of the most common non-transmitted diseases, leading cause of a series of ailments, of which nearly $15 \%$ of Viet Nam's population equal to 14 million of people are suffering from, among which 3 million are suffering from severe mental disorder [25]. Notwithstanding, the number of patients receiving treatment is relatively low, 2-3 persons out of 10 get 
medical care, but by medicine not psychiatric treatment [26].

Viet Nam is a country with relatively high number of criminals and the common penalty applied is imprisonment. Inmates in Viet Nam are confined in a quite crowded environment, according to Article 42 of the Criminal Law Enforcement Act, the minimum area for one prisoner is $2 \mathrm{~m}^{2}$. However, sometimes the overcrowded prison situation prevents this requirement to be met. The high incidence of physical illness, the average number of prisoners with HIV or drug addiction, and other issues which are the causes of mental disorders of any inmate in other countries lead to the possibilities of instability and psychiatric illness of prisoners in Viet Nam.

Legally, the Criminal Code of Viet Nam has promulgated several regulations about compulsory treatment for criminals, but only "for persons who are serving their penalties but are suffering from illness to the extent of losing their cognitive capability or the capability to control their acts" As mentioned, this is a judicial procedure decided by the Court, basing on the conclusion of the Medical Examination Council, may decide to send those persons to specialized medical establishments for compulsory treatment. After their recovery from illness, such persons shall continue serving their penalties, if they have no reasons for exemption from serving their penalties and the medical treatment duration shall be subtracted from the term of imprisonment imposed. When the head of the confinement facility senses the signals of illness, he will ask the Court (provincial level) to request forensic psychiatric examination and decide to apply compulsory treatment. Actually, prisons all have clinics and a team of physicians for medical examination and treatment. On the arrival at the camps, prisoners are checked and results are recorded in medical books. If they suffer from serious diseases, they will be treated at infirmary of the prison or taken to the state hospital. Notwithstanding, with current conditions of mental health care in Viet Nam as mentioned above, infra-structures make it hard for this concern to be dealt. According to Article 27 of the Criminal Law Enforcement Act, during the execution of a sentence of imprisonment, if showing any signs of mental illness, the patients will be taken to the separate area. Identifying signals of mental illness is not easy since not all prisons have psychiatrists and treatment procedures for those prisoners from the detection to the decision of compulsory applying is long in terms of legal process (the prison requires the Court to request forensic psychiatry expertise, after the assessment conclusion, the Court will make the decision to transfer the offender to a mental clinic) and assessing process (sufficient time needed for forensic psychiatric examination can even be up to 2-3 months to record, experiment and give accurate conclusions, during which period, if accordance to the law, prisoners are still in detention, far from the workplace of examiners). Hence, it will extend the length of time the patients are taken to the hospitals. For other prisoners with mild mental illness or other psychiatric conditions that have not been detected yet the treatment is quite difficult.

Criminals with mental illness convicted of sexual crimes have not received much concern over causes of crimes and criminal policies for them. Similar to other nations, in Viet Nam, sexual crimes are regarded as heinous and condemned vigorously. In the recent occurrence of many social crimes, lawmakers and judges of Viet Nam are facing pressure to impose more serious punishments on the offenders. If offenders with mental ailments charged with sexual crimes are not applied compulsory treatment as mentioned above, their punishments are basically the same, most of them get quite strict punishments, serve their penalties in detention and return to the society in the same manner as other prisoners. There have been no much studies, statistics or data about the recidivism rate in practice.

From listed issues plus comparison with practices in Germany and other countries, the 
following measures for criminals with mental disorders and sexual offenders are suggested:

+ A comprehensive survey and evaluation of mental health issues for inmates in prisons should be conducted to obtain full data on the type, the level as well as the structure and rate of mental disorders;

+ Studies on mental health conditions and medical procedures that are applicable and necessarily applied to offenders need developing from the practices of foreign countries;

+ Trainings of human resources for social works with specialization in psychological and mental health should be promoted and then this human resource should be used to assist jail supervisors in caring for and dealing with mental issues of evildoers so that mental ailments will be restricted and the efficiency of education reforms will be improved;

+ According to the requirements of citizens, privatization of mental clinics and health care centers for psychological treatments and mental disorders should be boosted in order to increase the population with specialization in psychological and mental issues so that detention centers and prisoners' families will have more options of compulsory treatments to choose from;

+ Prisons' officers should be allowed to make a direct decision to request forensic mental examination and after the results, they hand the documents to the Court for compulsory treatments instead of reporting to the Court in order to request forensic mental examination as is currently done. Some even suggest that camp administrators should make a direct decision on the application of compulsory treatments for prisoners instead of the Court; however, this proposal is unreasonable because it will lead to a breakdown in the rapport between the Court and the current criminal justice system, which operates on the principle of respecting the court, respecting and ensuring the validity of judgments; decisions and amendments of decisions for the convicted must be considered and decided by the Court. However, it is not necessary to involve the Court's decision in soliciting a forensic psychiatric assessment for inmates.

On the other hand, the competence agency of administration the criminal judgment execution, the Ministry of Public Security, Ministry of National Defense), should coordinate with the Ministry of Health in issuing regulations defining what signs are considered mental illness as a basis for prisons' administrators to decide on the separation or transferring prisoners from normal cells to private ones. Because whether the separation and transferring are right or wrong, quick or slow, it has a tremendous impact on the evildoers and people around them. The managing mechanism of living, working and medical care for those people within the detention should be improved to support criminals and guarantee the safety of the prisons.

More policies for sexual criminals should be added in the direction of:

+ Modifying the Penal Code with: 1, adding castration as content of compulsory treatments. Due to the lighter and more ethical nature, medical castration is mandatory for criminals before they are allowed to return to the community; 2, supplementing the application of probation or ban from residence penalties to sex offenders (additional penalties beyond the principal penalties, usually for those who have completed serving their imprisonments).

+ Amending the law on execution of criminal judgments so as to specify the order, procedures and competent subjects in organizing the implementation of this measure, of which the prisons' supervisors should be in charge under the medical 
management of the jurisdiction of Ministry of Health as the model of poison management to enforce the current death penalty.

+ Specifying stipulations on managing, monitoring, examining and patrolling sex offenders who have been returned to the community on the principle of regular management their stay, travel and contact; giving in time and prompt warnings for the society, coordinating with mental institutions to record psychiatric changes and conditions as well as the effectiveness of the chemical castration to propose the Court to re-apply the measure.

\section{Conclusion}

Securing mental health embraces a huge importance for the well- being of all individuals; in a normal environment, protection of mental health and dealing with mental disorders are difficult, let alone in the detaining environment, the mental health of inmates is difficult to be guaranteed as well as handled at the occurrence of diseases.

Mental disorder can exacerbate a prisoner s' detrimental health and environment, leading to a failure in achieving the goal of criminal reforms and social security. Mental ailments resulting in sexual disorders and then the execution of sexual offenses, if not resolved, will lead to ineffectiveness in crime handling and failure in preventing the risk of increasing this issue. Consequently, despite its institutional effort in addressing the issue, Viet Nam calls for more information from the practice of other countries which have been working on this.

Situations in Germany, the United States, the United Kingdom, Denmark and other nations are diverse, whereas in general they are all aware of the complexity and seriousness of mental illness the criminals are facing, at the same time, they are all more prosperous and developed than Viet Nam in terms of economic and medical conditions. Although their achievements and models are not immediately applicable in Viet Nam, their practical lessons are worthy of reference. Adjusting the policies for dealing with sexual offenders due to mental issues is a matter for Viet Nam to urgently improve on the institutional side by paying more attention to the additional penalties and mandatory treatments, chemical castration and community monitoring.

\section{References}

[1] H. Richard Lamb and Linda E. Weinberger, 'Persons with Severe Mental Illness in Jails and Prisons: A Review', published online: April 01, 1998, https://doi.org/10.1176/ps.49.4.483

[2] Richard J. Freeman and Ronald Roesch, 'Mental Disorder and the Criminal Justice System: A Review', International Journal of Law and Psychiatry, Vol. 12. 105-1 15, 1989.

[3] Annual Reports of The People Supreme Court in 2012, 2013, 2014.

[4] Marc Lehmann, 'Psychiatric care in the German prison system', International Journal of Prison Health, Vol.8 No. 37/4 2012, 135.

[5] Andrew Coyle, 'Understanding Prisons, Key issues in policy and practice', Open University Press, 123.

[6] Annual Reports of The Government on Execution of Judicial Judgments in 2014.

[7] Andrew Coyle, "Understanding Prisons", Open University Press, 61.

[8] Andrew Coyle, "Understanding Prisons", Open University Press, 61.

[9] Andrew Coyle, "Understanding Prisons", Open University Press, 62.

[10] European Commission, The SANCO Directorate General, Central Institute of Mental Health, 'Research Project Mentally Disordered Persons in European Prison Systems - Needs, Programmes and Outcome (EUPRIS)', Final Report ( October 31, 2007), 51.

[11] European Commission, The SANCO Directorate General, Central Institute of Mental Health, 'Research Project Mentally Disordered Persons in European Prison Systems - Needs, Programmes and Outcome (EUPRIS)', Final Report ( October 31, 2007), 51.

[12] H. Richard Lamb and Linda E. Weinberger, 'Persons with Severe Mental Illness in Jails and 
Prisons: A Review', published online: April 01, 1998 https://doi.org/10.1176/ps.49.4.483 (cited from Steadman HJ, Cocozza JJ. Seattle, National Coalition for the Mentally Ill in the Criminal Justice System, 'Illness in America's Prisons' 1993).

[13] U.S. Department of Justice, Office of Justice Programs, Bureau of Justice Statistics, 'An Analysis of Data on Rape and Sexual Assault, Sex Offenses and Offenders'

[14] Roger H. Peters, Harry K. Wexler, 'Substance abuse treatment for adults in the criminal justice system: Treatment Improvement' Protocol TIP 44, (U.S. department of health and human services, Public Health Service, Substance Abuse and Mental Health Services Administration, Center for Substance Abuse Treatment).

[15] Marc Lehmann, 'Psychiatric care in the German prison system', International Journal of Prison Health, Vol. 8 No. 37/4 2012, 135.

[16] Section 126 of German Prison Act: "The number of specialist staff for the socio-therapeutic institution shall be such as to also secure aftercare for the prisoners to the extent that such care cannot be otherwise guaranteed".

[17] Center for Substance Abuse Treatment. 'Substance Abuse Treatment for Adults in the Criminal Justice System', Treatment Improvement Protocol (TIP) Series, No. 44.

[18] European Commission, The SANCO Directorate General, Central Institute of Mental Health, 'Research Project Mentally Disordered Persons in European Prison Systems - Needs, Programmes and Outcome (EUPRIS)', Final Report ( October 31, 2007), 125.

[19] European Commission, The SANCO Directorate General, Central Institute of Mental Health, 'Research Project Mentally Disordered Persons in European Prison Systems - Needs, Programmes and Outcome (EUPRIS)', Final Report ( October 31, 2007), 119.

[20] The European Committee for the Prevention of Torture and Inhuman or Degrading Treatment or Punishment (CPT), Report to the German Government on the visit to Germany carried out by from 25 November to 7 December 2010, 56.

[21] Fred S. Berlin, 'Sex offender treatment and Legislation', J Am Acad Psychiatry Law 31:510 13, 2003; Scott CL, Holmberg T, 'Castration of Sex Offenders: Prisoners' Rights Versus Public Safet Castration of Sex Offenders: Prisoners' Rights Versus Public Safety' J Am Acad Psychiatry Law 31:502-9, 2003.

[22] Compelling Chemical Castration Statistics, http://healthresearchfunding.org/16-compellingchemical-castration-statistics

[23] European Commission, The SANCO Directorate General, Central Institute of Mental Health, 'Research Project Mentally Disordered Persons in European Prison Systems - Needs, Programmes and Outcome (EUPRIS)', Final Report (October 31, 2007), 134.

[24] European Commission, The SANCO Directorate General, Central Institute of Mental Health, 'Research Project Mentally Disordered Persons in European Prison Systems - Needs, Programmes and Outcome (EUPRIS)', Final Report ( October 31, 2007), 120.

[25] Thuỷ Lâm, 'Alarming issue: nearly 14 million Vietnamese are mental disorders and solution ("Báo động: Gần 14 triệu người Việt bị rối loạn tâm thần và giải pháp”), http://vietnamnet.vn/vn/suc-khoe/ga-n-14-trie-unguo-i-vie-t-bi-roi-loan-tam-tha-n-277487.html.

[26] Thuý Hạnh, 'Nearly 14 million Vietnamese are mental disorders' ("Gần 14 triệu người Việt bị rối loạn tâm thần”), https://laodong.vn/dien-dan/baodong-gan-14-trieu-nguoi-viet-bi-roi-loan-tamthan-va-giai-phap-633032.bld 


\title{
Chính sách đối với phạm nhân, người thực hiện các tội phạm về tình dục với các rối loạn tâm thần: Thực tiễn tại Đức, một số quốc gia khác và các khuyến nghị đối với Việt Nam
}

\author{
Lê Lan Chi
}

Khoa Luật, Đại học Quốc gia Hà Nội, 144 Xuân Thuỷ, Cầu Giấy, Hà Nội, Việt Nam

Tóm tắt: Các rối loạn tâm thần tác động tiêu cực đến quá trình chấp hành án của phạm nhân và người thực hiện các tội phạm về tình dục cũng như đến việc thực hiện mục tiêu cải tạo và kiểm soát tội phạm. Do đó, nhiều quốc gia trên thế giới đã có những chính sách đặc thù đối với các đối tượng này. Bài viết góp phần làm rõ cơ sở, nội dung của những chính sách đó và đưa ra các khuyến nghị đối với Việt Nam nhằm góp phần bảo đảm quyền con người cũng như giải quyết những vấn đề hữu quan của thực tiễn tư pháp hình sự ở Việt Nam hiện nay.

Tù khoá: Rối loạn tâm thần, phạm nhân, môi trường giam giữ, trị liệu tâm lý, tội phạm về tình dục, hình phạt, triệt dục hoá học, triệt dục phẫu thuật. 